\title{
Electrosurgical bipolar vessel sealing versus conventional clamping and suturing for total abdominal hysterectomy
}

\author{
Mustafa Ulubay ${ }^{1}$, Mehmet Ferdi Kinci², \\ Ramazan Erda Pay ${ }^{3}$, Murat Dede 4
}

\begin{abstract}
Objectives: To compare the use of Electrosurgical bipolar vessel sealing LigaSure ${ }^{\mathrm{TM}}$ small jaw instrument (LSJI) with conventional suture ligation in total abdominal hysterectomy (TAH).

Methods: In this retrospective study 80 patients who underwent hysterectomy in the Gynecology and Obstetrics Department of Gulhane Education and Research Hospital between April 2017 and August 2018 were included. Two different groups that underwent Electrosurgical bipolar vessel sealing LigaSure ${ }^{T M}$ small jaw instrument (LSJI) and conventional suture ligation in hysterectomy operation were analyzed retrospectively. The parameters evaluated and compared between the two groups include operation time, intraoperative blood loss, duration of hospitalization and incision length.

Results: Among the parameters we compared between the two groups, there was no statistically significant difference between the amount of intraoperative blood loss ( $p: 0.68)$ and the incision length ( $p: 0.65)$. Among the parameters we compared between the two groups, a statistically significant difference was observed between the operation time (p:0.016) and the duration of hospitalization (p:0.01).

Conclusion: Our comparison of LSJI vs. conventional ligation in hysterectomy revealed a significant difference only in operative time, where surgeries involving conventional ligation were shorter. On the other hand, incision length was evaluated in our study which has not been addressed in previous studies. There is also a need for multi-center studies that include more patients and evaluate cost-effectiveness.
\end{abstract}

KEYWORDS: Conventional Sutures, Operation time, Total Abdominal Hysterectomy, Vessel Sealing System.

doi: https://doi.org/10.12669/pjms.38.1.4197

How to cite this:

Ulubay M, Kinci MF, Pay RE, Dede M. Electrosurgical bipolar vessel sealing versus conventional clamping and suturing for total abdominal hysterectomy. Pak J Med Sci. 2022;38(1):156-161. doi: https://doi.org/10.12669/pjms.38.1.4197

This is an Open Access article distributed under the terms of the Creative Commons Attribution License (http://creativecommons.org/licenses/by/3.0), which permits unrestricted use, distribution, and reproduction in any medium, provided the original work is properly cited.

1. Mustafa Ulubay,

Assistant Professor,

University of Health Sciences,

Gulhane Education and Research Hospital,

Obstetrics and Gynecology Department, Ankara, Turkey.

2. Mehmet Ferdi KINCI, M.D,

Mugla Sitki Kocman University Education and Research Hospital, Obstetrics and Gynecology Department, Mugla, Turkey.

3. Ramazan Erda Pay, M.D,

Bingol State Hospital,

Obstetrics and Gynecology Department, Bingöl, Turkey.

4. Prof. Murat DEDE,

Special Anadolu Health Center,

Obstetrics and Gynecology Department, Istanbul, Turkey

Correspondence:

Mehmet Ferdi Kinci, M.D.

Mugla Sitki Kocman University Education and Research Hospital, Obstetrics and Gynecology Department, Mugla, Turkey.

Email: drferdikinci@gmail.com

* Received for Publication:

January 22, 2021

* Revision Received:

* Revision Accepted:
August 16, 2021

August 30, 2021

\section{INTRODUCTION}

Hysterectomy is one of the most commonly performed surgical procedures in women. Estimates suggest that one in nine women will undergo hysterectomy during their lifetime and that approximately 600,000 procedures are performed each year in the United States. ${ }^{1}$ The first technique introduced was total abdominal hysterectomy (TAH) which was mostly succeeded by minimally invasive methods over time. Although vaginal hysterectomy $(\mathrm{VH})$ remains the gold standard, technological advances have enabled a trend towards Laparoscopic Hysterectomy (LH) and Robotic Hysterectomy (RH), numerous variations of which have also been described. ${ }^{2-4}$ Lately, conventional suture ligation techniques employed 
in such procedures are being replaced by laser applications and various electrothermal and ultrasonic coagulation methods. ${ }^{5,6}$

During electrothermal coagulation, a controlled high-power current at low voltage from a device is used to melt the collagen and elastin in tissue, leading to permanent fusion of the vascular layers and obliteration of the lumen. The device fuses vessels up to $2-7 \mathrm{~mm}$ in diameter. ${ }^{7}$ In addition to minimally invasive procedures, the use of electrothermal coagulation has been expanded within years to hemorrhoidectomy, thyroidectomy, and certain abdominal surgeries. ${ }^{5,6}$ Conventional versus technology-aided hysterectomy modalities have been compared by some studies both for intraoperative and postoperative parameters.

In the present study, we have evaluated blood loss, size of incision, duration of operation, volume of the uterus, and length of hospitalization with Ligasure vessel sealing system in comparison to conventional ligation at hysterectomy.

\section{METHODS}

This retrospective study was approved by the local clinical research ethics committee (CREC Decision No: 2020-65). It was performed at the Gulhane Education and Research Hospital, Ankara, Turkey over the period from April 2017 to August 2018. Patient data were scanned through the hospital data system. The data of $63 \mathrm{TAH}+$ Bilateral salpingo-oophorectomy (BSO) and 17 $\mathrm{TAH}+$ Bilateral salpingectomy patients who had the inclusion criteria were scanned.

Pre-Surgical procedure: All patients were questioned for their detailed medical history before their surgery. Their age, height, weight, body mass index (BMI), gravidity, parity, and history of previous abdominal surgery were recorded. During the course of their physical examination, bimanual and speculum examination was carried out followed by transvaginal ultrasound (TV US). Further imaging or diagnostic tests were requested when deemed necessary. Endometrial biopsy samples were collected from the patients at risk who presented with abnormal uterine bleeding. All patients had complete blood count and routine biochemical testing done before the surgery. Patients who experienced any concomitant surgical procedures and those who underwent hysterectomy for gynecologic cancer were excluded from this study.

Surgical procedure: For each case, perioperative prophylactic, intravenous (IV) first-generation cephalosporin antibiotic (cefazolin sodium 1 g) was administered. All patients underwent extrafascial TAH (Type-1) \pm bilateral salpingooophorectomy or bilateral salpingectomy procedure. Abdominal access was gained through a transverse (Pfannenstiel) incision. Round ligament, suspensory ligament of the ovary or proper ovary ligament, uterine artery, cardinal ligament, and uterosacral ligaments were detached from the uterus. For conventional abdominal hysterectomy, clamping and cutting were followed by tying with polyglactin suture material (Vicryl size: 0 , Ethicon, NJ, USA). In the LigaSure ${ }^{\mathrm{TM}}$ small jaw instrument (LSJI; Medtronic, Boulder, CO, USA) (Valleylab, CO, USA) method, clamping was followed by sealing and cutting. The closure of the vaginal cuff was secured a single-layer continuous running suture. Once hemostasis was checked, the peritoneum was closed with a 2/0 Vicryl suture ${ }^{\mathrm{TM}}$ (Polyglactin 910 Suture, Ethicon Co, USA) and fascia with a Vicryl suture size:0. In patients with a subcutaneous fat tissue thicker than $2 \mathrm{~cm}$, a subcutaneous approximation suture was placed. The skin was then closed with a 4/0 Vicryl Rapide suture $^{\mathrm{TM}}$ (Polyglactin 910 Suture, Ethicon Co, USA). Post-operative Follow-up: Patients were given 75 mg I.M. Diclofenac Sodium BID (Diclomec 75 $\mathrm{mg} / 3 \mathrm{~mL}$ IM Ampoule, Solution for Injection, Abdi Ibrahim, Istanbul, Turkey) used as postoperative analgesia. Study arms were compared in terms of their operative time, blood loss, postoperative complications, hospital stay, and incision length. In this comparison, the operative time was considered as the time elapsed from anesthesia induction to awakening. Postoperative hematocrit (HCT) values of the patients were measured at 8 $\mathrm{h}$ and 24 hour after the procedure. The length of incision was determined by a first-year resident using a ruler during the wound dressing applied at 24 hour after the procedure. Uterine volumes were calculated in $\mathrm{cm}^{3}$ by multiplying all three dimensions as reported in the pathology report.

Statistical analysis: Statistical analysis of data was performed using IBM SPSS (Statistical Package for Social Sciences) for Windows 15.0. Descriptive statistics (mean, standard deviation) were used to present the study data. Before quantitative characteristics were compared, the decision as to whether they have a normal distribution was made based on skewness and kurtosis of distribution. A comparison of groups was done using independent samples t-test in case of continuous variables and using the Chi-square test in case of categorical 
Table-I: Review of previous studies.

\begin{tabular}{|c|c|c|c|c|c|c|c|}
\hline Author(s) & Date & Device & Patient Number & Blood Loss & $\begin{array}{l}\text { Operative } \\
\text { Time }\end{array}$ & Complication & Hospital Stay \\
\hline $\begin{array}{l}\text { Maher M. } \\
\text { et al. }{ }^{20}\end{array}$ & $\begin{array}{l}\text { January } \\
2009 \text { - } \\
\text { December } \\
2009\end{array}$ & $\begin{array}{l}\text { Ligasure } \\
\text { vessel seal- } \\
\text { ing system }\end{array}$ & 50 vs. 50 & $\begin{array}{l}3.29 \pm 2.02 \\
\text { vs. } 3.90 \pm \\
1.93 \\
(p=0.13) \\
\text { Hematocrit }\end{array}$ & $\begin{array}{l}59.98 \pm 10.31 \\
\text { vs. } 74.30 \pm \\
12.81 \mathrm{~min} \\
(p<0.0001)\end{array}$ & $\begin{array}{l}\text { Bladder injury, } \\
\text { Vault bleeding, } \\
\text { Wound infection } \\
2 \% \text { vs. Blad- } \\
\text { der injury } 4 \% \text {, } \\
\text { Wound infection } \\
2 \%\end{array}$ & $\begin{array}{l}3.98 \pm 0.62 \text { vs. } \\
4.04 \pm 0.81 \\
\text { days; } \\
p=0.68\end{array}$ \\
\hline $\begin{array}{l}\text { Briones } \\
\text { Landa } \\
\text { CH. et } \\
\text { al. }^{11}\end{array}$ & $\begin{array}{l}\text { March } \\
2007 \text { - } \\
\text { February } \\
2008\end{array}$ & $\begin{array}{l}\text { Bipolar } \\
\text { plasmaki- } \\
\text { netics ves- } \\
\text { sel sealing }\end{array}$ & 47 vs. 47 & $\begin{array}{l}209 \pm 92 \text { vs. } \\
330 \pm 113 \\
m L \\
(p<0.003)\end{array}$ & $\begin{array}{l}82.9 \pm 12.69 \\
\text { vs. } 99.1 \pm \\
18.4 \min \\
(p<0.001) .\end{array}$ & - & $\begin{array}{l}2.06 \pm 0.24 \\
\text { vs. } 3.2 \pm 0.89 \\
\text { days, } p<0.001\end{array}$ \\
\hline $\begin{array}{l}\text { Wang K. } \\
\text { et al. }{ }^{10}\end{array}$ & $\begin{array}{l}\text { October } \\
2013 \text { - Oc- } \\
\text { tober } 2015\end{array}$ & $\begin{array}{l}\text { Ligasure } \\
\text { sealing } \\
\text { vessel } \\
\text { system }\end{array}$ & $\begin{array}{l}48 \text { vs. } 48 \text { cervi- } \\
\text { cal cancer }\end{array}$ & $\begin{array}{l}473.28 \pm \\
96.43 \mathrm{vs} . \\
738.15 \pm \\
102.81 \mathrm{~mL} \\
\mathrm{p}<0.05\end{array}$ & $\begin{array}{l}161.79 \pm \\
32.47 \\
\text { vs. } \\
212.56 \pm \\
31.05 \\
\min p<0.05\end{array}$ & $\begin{array}{l}9(18.8 \%) \\
\text { vs. } \\
18(37.5 \%) \\
p<0.05\end{array}$ & $\begin{array}{l}13.28 \pm 3.62 \\
\text { vs. } \\
16.97 \pm 4.25 \\
\text { days } \\
p<0.05\end{array}$ \\
\hline $\begin{array}{l}\text { Aydin C. } \\
\text { et al. }{ }^{9}\end{array}$ & $\begin{array}{l}\text { January } \\
2010 \text { - Oc- } \\
\text { tober } 2010\end{array}$ & $\begin{array}{l}\text { Ligasure } \\
\text { vessel seal- } \\
\text { ing system }\end{array}$ & $\begin{array}{l}44 \text { vs. } 44 \text { large } \\
\text { uterus }\end{array}$ & $\begin{array}{l}0.99 \pm 0.74 \\
\text { vs. } \\
1.13 \pm 0.81 \\
H G B \\
p=0.328\end{array}$ & $\begin{array}{l}109.91 \pm 26.5 \\
\text { vs. } \\
124.77 \pm \\
35.51 \mathrm{~min} \\
\mathrm{p}=0.029\end{array}$ & $\begin{array}{l}\text { Wound infec- } \\
\text { tion }(2.2 \%) \text { vs. } \\
\text { Bladder injury, } \\
\text { Hemorrhage } \\
(2.2 \%)\end{array}$ & $\begin{array}{l}5.92 \pm 2.63 \mathrm{vs} . \\
5.95 \pm 1.82 \\
\text { days }\end{array}$ \\
\hline $\begin{array}{l}\text { Rossetti } \\
\text { D. et al. }{ }^{12}\end{array}$ & $\begin{array}{l}\text { January } \\
2001- \\
\text { October } \\
2013 .\end{array}$ & $\begin{array}{l}\text { Ligasure } \\
\text { vessel seal- } \\
\text { ing system }\end{array}$ & $\begin{array}{l}23 \text { vs. } 26 \\
\text { peripartum } \\
\text { hysterectomy }\end{array}$ & $\begin{array}{l}1900(700- \\
4000) \text { vs. } \\
2700(800- \\
8000) \mathrm{mL} \\
\mathrm{p}=0.001\end{array}$ & $\begin{array}{l}110(60-240) \\
\text { vs. } 170(85- \\
320) \min \\
p=0.06\end{array}$ & $\begin{array}{l}6 / 23(26 \%) \text { vs. } \\
4 / 26(15 \%) p= \\
0.35\end{array}$ & $\begin{array}{l}6(4-9) \text { vs. } 8(5- \\
10) \text { days } \\
p=0.78\end{array}$ \\
\hline $\begin{array}{l}\text { Türkç- } \\
\text { üoğlu I. } \\
\text { et al. }\end{array}$ & $\begin{array}{l}\text { July } 2010 \\
\text { - October } \\
2010\end{array}$ & $\begin{array}{l}\text { Ligasure } \\
\text { vessel seal- } \\
\text { ing system }\end{array}$ & 22 vs. 31 & $\begin{array}{l}157.1 \pm 89.1 \\
\text { vs. } \\
142.3 \pm 40.5 \\
\mathrm{~mL} ; \mathrm{p}= \\
0.749\end{array}$ & $\begin{array}{l}90.2 \pm 20.6 \\
\text { vs. } 92.1 \pm \\
21.1 \text { min; } p= \\
0.962\end{array}$ & - & $\begin{array}{l}3.6 \pm 2.4 \text { vs. } \\
3.2 \pm 1 \text { days } \\
p=0.527\end{array}$ \\
\hline $\begin{array}{l}\text { Hagen B. } \\
\text { et al. }{ }^{17}\end{array}$ & $\begin{array}{l}\text { June } \\
2002- \\
\text { April } \\
2003\end{array}$ & $\begin{array}{l}\text { Ligasure } \\
\text { vessel seal- } \\
\text { ing system }\end{array}$ & 16 vs.16 & $\begin{array}{l}303 \text { vs. } 298 \\
\text { mL }\end{array}$ & $\begin{array}{l}61.7 \text { vs. } 54.5 \\
\min \end{array}$ & $\begin{array}{l}\text { Wound infection } \\
(18.75 \%) \text {, } \\
\text { Wound rup- } \\
\text { ture }(6.25 \%) \text { vs. } \\
\text { Wound infection } \\
(6.25 \%), \text { Vault } \\
\text { bleeding }(6.25 \%)\end{array}$ & 10 vs. 6 days \\
\hline $\begin{array}{l}\text { Bruno R. } \\
\text { et al. }{ }^{18}\end{array}$ & - & $\begin{array}{l}\text { Ligasure } \\
\text { impact, } \\
\text { using the } \\
\text { Force Tri- } \\
\text { ad energy } \\
\text { platform }\end{array}$ & - & $\begin{array}{l}80 \text { vs. } 122 \\
\mathrm{~mL}(34 \% \\
\text { difference })\end{array}$ & $\begin{array}{l}35 \text { vs. } 50 \\
\min (30 \% \\
\text { difference) }\end{array}$ & $\begin{array}{l}4 \text { vs. } 8 \text { patients } \\
\text { with blood } \\
\text { transfusion }\end{array}$ & $\begin{array}{l}2.6 \text { vs. } 3.5 \\
\text { days }\end{array}$ \\
\hline $\begin{array}{l}\text { Lakeman } \\
\text { M. et al. }{ }^{19}\end{array}$ & $\begin{array}{l}\text { January } \\
2005 \text { - } \\
\text { Septem- } \\
\text { ber } 2006\end{array}$ & $\begin{array}{l}\text { Ligasure } \\
\text { vessel seal- } \\
\text { ing system }\end{array}$ & 28 vs. 29 & $\begin{array}{l}200(33- \\
1500) \text { vs. } \\
335(70- \\
1750) \\
p=0.08\end{array}$ & $\begin{array}{l}69(29-130) \\
\text { vs. } 63(38- \\
124) \min \\
p=0.62\end{array}$ & $\begin{array}{l}\text { Ileus requiring } \\
\text { re operation, Fe- } \\
\text { ver of unknown } \\
\text { origin, Throm- } \\
\text { boembolism 3\% } \\
\text { vs. Infected he- } \\
\text { matoma, Wound } \\
\text { dehiscence, } \\
\text { Pneumonia 3\% }\end{array}$ & $\begin{array}{l}4(2-32) \text { vs. } 5 \\
(3-11) \text { days; } \\
\mathrm{p}=0.26\end{array}$ \\
\hline
\end{tabular}




\begin{tabular}{|c|c|c|c|c|c|c|c|}
\hline $\begin{array}{l}\text { Supra- } \\
\text { songsin } \\
\text { C. and } \\
\text { Boon- } \\
\text { yakitanon } \\
\text { M. }^{13}\end{array}$ & $\begin{array}{l}\text { Novem- } \\
\text { ber } 2010 \text { - } \\
\text { December } \\
2011\end{array}$ & $\begin{array}{l}\text { Electrosur- } \\
\text { gical Bipo- } \\
\text { lar Vessel } \\
\text { Sealing }\end{array}$ & 30 vs. 30 & $\begin{array}{l}248.33 \pm \\
154.52 \mathrm{vs} \\
357.00 \pm \\
245.34 \mathrm{~mL} \\
\mathrm{p}=0.04\end{array}$ & $\begin{array}{l}70.03 \pm 21.06 \\
\text { vs. } 92.3 \pm \\
26.54 \mathrm{~min} ; \\
\mathrm{p}<0.001\end{array}$ & $\begin{array}{l}\text { Bladder injury, } \\
\text { Infected wound, } \\
\text { Infected vaginal } \\
\text { stump } 3.3 \% \text { vs. } \\
\text { Infected wound } \\
6.6 \% \text {, Infected } \\
\text { vaginal stump } \\
3.3 \%\end{array}$ & $\begin{array}{l}4.13 \pm 0.35 \text { vs. } \\
4.4 \pm 0.67 \\
p=0.06\end{array}$ \\
\hline $\begin{array}{l}\text { Dessole S. } \\
\text { et al. }{ }^{14}\end{array}$ & $\begin{array}{l}\text { August } \\
2000\end{array}$ & $\begin{array}{l}\text { Bipolar } \\
\text { electro- } \\
\text { cautery } \\
\text { scissors }\end{array}$ & 50 vs. 50 & $\begin{array}{l}2.9 \text { vs. } 5.9 \\
\text { HTC } \% \\
\text { p }<0.001\end{array}$ & $\begin{array}{l}91 \pm 15 \text { vs. } \\
121 \pm 32 \\
\text { min; } p<0.01\end{array}$ & $\begin{array}{l}\text { There was no } \\
\text { increase in the } \\
\text { complication } \\
\text { rate. }\end{array}$ & - \\
\hline $\begin{array}{l}\text { Lauroy } \\
\text { A. et al. }{ }^{15}\end{array}$ & $\begin{array}{l}\text { February } \\
2005-\mathrm{Au}- \\
\text { gust } 2018\end{array}$ & $\begin{array}{l}\text { Ligasure } \\
\text { vessel seal- } \\
\text { ing system }\end{array}$ & $\begin{array}{l}29 \text { vs. } 57 \\
\text { peripartum } \\
\text { hysterectomy }\end{array}$ & $\begin{array}{l}3198 \text { vs. } \\
4223 \mathrm{~mL} ; \mathrm{p} \\
=0.02\end{array}$ & $\begin{array}{l}45.62(10- \\
120) \text { vs. } \\
38.05(8-114) \\
\min ; \mathrm{p}=0.1\end{array}$ & $\begin{array}{l}8(27.5) \text { vs. } 19 \\
(33.3) ; p=0.25\end{array}$ & - \\
\hline $\begin{array}{l}\text { Talaat } \\
\text { A. and } \\
\text { Makboul } \\
\text { G. }{ }^{16}\end{array}$ & $\begin{array}{l}\text { March } \\
2010 \text { - } \\
\text { January } \\
2012\end{array}$ & $\begin{array}{l}\text { The Ul- } \\
\text { tracision } \\
\text { (Harmonic } \\
\text { Shears) } \\
\text { device }\end{array}$ & 30 vs. 30 & $\begin{array}{l}74.9 \pm 56.7 \\
\text { vs. } 139.4 \pm \\
118.4 \mathrm{~mL} ; \mathrm{p} \\
=0.005\end{array}$ & $\begin{array}{l}40.3 \pm 19.7 \\
\text { vs. } 55.6 \pm \\
22.4 \text { min; } p= \\
0.003\end{array}$ & $10 \%$ vs. $10 \%$ & - \\
\hline
\end{tabular}

variables. For all results, the level of statistical significance was set to $\mathrm{p}<0.05$.

Evaluation of other studies about hysterectomy with vessel sealing systems: Previous publications were identified through a search in "Google Scholar" and "Pubmed" without date restriction. The key words selected for the search were: hysterectomy, abdominal hysterectomy, vessel sealing system, LigaSure® Electrosurgical Vessel Sealer, and Conventional Suture Technique. We did not include unpublished papers. Our search produced 13 eligible hits. We have reviewed these papers to extract the study date, sample size (n), applied methods, amount of blood loss, duration of surgery, complication rates, and hospital stay (Table-I).

\section{RESULTS}

Based on the discretion of the surgeon and the menopausal status of the women, 63 patients underwent $\mathrm{TAH}+\mathrm{BSO}$, and 17 patients underwent TAH+bilateral salpingectomy. Accordingly, in

Table-II: Patients by indication for hysterectomy.

\begin{tabular}{lcc}
\hline & $\begin{array}{c}\text { LSJI } \\
n(\%)\end{array}$ & $\begin{array}{c}\text { Conventional } \\
n(\%)\end{array}$ \\
\hline Uterine Myoma & $20(50 \%)$ & $19(47.5 \%)$ \\
Endometriosis & $5(12.5 \%)$ & $6(15 \%)$ \\
Abnormal Uterine Bleeding & $12(30 \%)$ & $12(30 \%)$ \\
Endometrial Hyperplasia & $3(7.5 \%)$ & $3(7.5 \%)$ \\
\hline
\end{tabular}

the TAH+BSO group, 30 patients were treated with LSJI and 33 patients were treated with the conventional method. In the TAH+bilateral salpingectomy group, on the other hand, 10 patients were treated with LSJI and 7 patients were treated with the conventional method. Patient indications for hysterectomy are given in Table-II.

The study arms had no significant difference in terms of gravidity, parity, BMI, or preoperative HCT values of patients $(\mathrm{p}>0.05)$ Table-III. In our postoperative analysis, HCT value at $24 \mathrm{~h}$ after the procedure, uterine volume, incision length and duration of hospitalization were also not significantly different $(p>0.05)$. On the other hand, operative time, HCT value at $8 \mathrm{~h}$ after the procedure, and postoperative hospital stay were significantly different between the $\operatorname{arms}(\mathrm{p}<0.05)$ Table-III and IV.

Postoperative complications experienced by the patients were wound infection in two patients and vaginal cuff hematoma in one patient at the LSJI arm, whereas one patient developed wound infection and one patient had cuff dehiscence in conventional ligation arm.

Table-III: Demographic characteristics of the patients.

\begin{tabular}{lcc}
\hline & $\begin{array}{c}\text { LSJI } \\
(\text { mean } \pm S D)\end{array}$ & $\begin{array}{c}\text { Conventional } \\
(\text { mean } \pm S D)\end{array}$ \\
\hline Gravidity $(\mathrm{n})$ & $3.02 \pm 1.54$ & $3.35 \pm 1.16$ \\
Parity $(\mathrm{n})$ & $2.1 \pm 0.84$ & $2.67 \pm 0.97$ \\
BMI $\left(\mathrm{kg} / \mathrm{m}^{2}\right)$ & $27.4 \pm 3.74$ & $25.69 \pm 2.1$ \\
\hline
\end{tabular}


Table-IV: Preoperative and postoperative characteristics of the patients.

\begin{tabular}{lccc}
\hline & LSJI (mean \pm SD) & Conventional (mean \pm SD) & $p$-value \\
\hline Preoperative HTC $(\%)$ & $37.4 \pm 4.01$ & $36.03 \pm 2.72$ & 0.069 \\
Postoperative 8 h HTC (\%) & $33.9 \pm 3.67$ & $32.33 \pm 2.58$ & 0.026 \\
Postoperative 24 h HTC (\%) & $31.4 \pm 3.73$ & $30.32 \pm 2.61$ & 0.10 \\
HTC reduction* & $5.95 \pm 2.63$ & $5.71 \pm 2.74$ & 0,688 \\
Uterine Volume $\left(\mathrm{cm}^{3}\right)$ & $472.5 \pm 412.8$ & $392.51 \pm 128.04$ & 0.24 \\
Incision Length $(\mathrm{cm})$ & $15.5 \pm 1.9$ & $14.81 \pm 1.27$ & 0.65 \\
Operative Time (min) & $104.5 \pm 42.9$ & $86.62 \pm 15.82$ & 0.016 \\
Duration of Hospitalization (days) & $2.47 \pm 0.59$ & $3.17 \pm 0.71$ & 0.01 \\
\hline
\end{tabular}

${ }^{*}$ HTC at postoperative 24 hour - preoperative HTC.

\section{DISCUSSION}

Hysterectomy is the most common gynecological surgery across the globe. Although the advent of the minimally invasive techniques has led to a gradual decrease in the TAH rate, it remains the most frequent method. ${ }^{2}$ As the utilization of various technology-aids raised over the years, conventional techniques have been compared in numerous aspects versus these technological modalities (Table-IV). Here, we have compared the LSJI method and the conventional method of ligation applied in hysterectomy in terms of HTC decrease, uterine volume, length of incision, operative time, and hospital stay.

We have not detected a significant difference in HCT values as measured before the surgery and $24 \mathrm{~h}$ after the surgery (p:0.069, p:0.10, respectively). On the other hand, HTC measured $8 \mathrm{~h}$ after the surgery was significantly higher in the LSJI arm (p:0.026). Blood loss was estimated by subtracting the preoperative HTC value from the postoperative value at $24 \mathrm{~h}$, which did not yield a significant difference between the study arms (p:0.688). In the previous studies, blood loss has been estimated in $\mathrm{mL}$ depending on the change in either HCT or hemoglobin (HGB) or through EBL (estimated blood loss) calculation. Although some studies are suggesting that a bipolar vessel sealing system does not affect operative blood loss, ${ }^{8-10}$ there are also reports of a reduction in operative blood loss. ${ }^{10-16}$ Moreover, no p-value has been specified in some studies, which does not allow a make any robust inferences. ${ }^{17,18}$

Operative time is one of the parameters which is included among the criteria used in a comparison of LSJI vs. conventional methods in hysterectomy. In our cohort, operative time was longer in the LSJI arm as compared to the arm of the conventional method of ligation in hysterectomy (p:0.016). This result is in line with the results of Lauroy A et al. and Lakeman et al. ${ }^{15,19}$ In our opinion, the longer operative time in LSJI surgeries results from the uncontrolled minor bleedings and the need for additional sutures. In other studies, on contrary, a shorter duration of operation was counted when LSJI is employed than when conventional methods were used. . $^{-14,16,18,20}$ Such studies argue LSJI is timesaving for surgery as it enables a single-step accomplishment of ligation which otherwise has to be done through clamping, cutting, and suturing.

Recently, cosmetic outcomes have a higher impact on the overall assessment of surgical success. In patients who are ineligible for minimally invasive surgical procedures, (laparoscopy/robotic surgery) location and size of the incision to conduct a laparotomy are of utmost importance. From the obstetrics point of view, the length of incision in Cesarean sections has been evaluated. ${ }^{21,22}$ The incision length, however, has not yet been explored in the hysterectomy setting. In our experience, hysterectomies implemented with LSJI vs. conventional ligation method were not statistically different in terms of incision length (p:0.65). A paramount effect on incision length is exerted by the size of the uterus to be removed. In our study, the mean uterine volumes were not significantly different between the groups (p:0.24) which allows for a healthier evaluation of incision length.

Duration of hospitalization due to a surgical procedure is crucial to avoid hospital infections and to improve cost-effectiveness. There was a significant difference in hospital stay between the two groups of our study (p:0.01). Although part of the previous studies has reported comparable results to ours, ${ }^{6,12,19,20}$ some studies achieved shorter inpatient stay for hysterectomy patients who were treated with LSJI. 
Limitations of the study: The present study does not involve any post-operative pain or cost analysis. This design characteristic is one of the limitations of our study.

Strengths of the study: Incision length is evaluated in our study which has not been addressed in previous studies.

\section{CONCLUSION}

Our comparison of LSJI vs. conventional ligation in hysterectomy revealed a significant difference only in operative time, where surgeries involving conventional ligation were shorter. In our study, the duration of hospital stays of patients who underwent surgery with LSJI was shorter. It is an advantage of operating with LSJI in protection against hospital infections, which increases as the duration of hospitalization increases. None of the other parameters included in our analyses showed any significant difference.

Financial Support: None.

Disclosure: None.

\section{REFERENCES}

1. Wu JM, Wechter ME, Geller EJ, Nguyen TV, Visco AG. Hysterectomy rates in the United States, 2003. Obstet Gynecol. 2007;110(5):1091-1095. doi: 10.1097/01. AOG.0000285997.38553.4b

2. Sandberg EM, Twijnstra AR, Driessen SR, Jansen FW. Total laparoscopic hysterectomy versus vaginal hysterectomy: a systematic review and meta-analysis. J Minim Invasive Gynecol. 2017;24(2):206-217. e222. doi:10.1016/j.jmig.2016.10.020

3. Albright BB, Witte T, Tofte AN, Chou J, Black JD, Desai VB, et al. Robotic versus laparoscopic hysterectomy for benign disease: a systematic review and meta-analysis of randomized trials. J Minim Invasive Gynecol. 2016;23(1):18-27. doi: 10.1016/j.jmig.2015.08.003

4. Sezgin B, Camuzcuoğlu A, Kucuk M, Camuzcuoglu H. Bilateral uterine artery coagulation in laparoscopic hysterectomy for benign disease in uteri more than $1000 \mathrm{~g}$. J Obstet Gynaecol Res. 2020;46(1):133-139. doi: 10.1111/jog.14148

5. Mehta S, Singla A. Vaginal Total Hysterectomy in Benign Indications: Hysterectomy Techniques with Bipolar Diathermy System. Hysterectomy: Springer. 2018;1429-1441. doi: 10.1007/978-3-319-22497-8_118

6. Turkcuoglu I, Melekoglu R. Total Abdominal Hysterectomy with Electrosurgical Bipolar Vessel Sealing. Hysterectomy: Springer. 2018;1179-1188. doi: 10.1007/978-3-319-22497-8_94

7. Artale RC, Moua T, Sharp RM. Vessel sealing instrument: Google Patents; 2016.

8. Turkcuoglu I, Kafkasli A, Dogan C, Tanrikut E. Tissue damage in abdominal hysterectomy performed with a vessel sealing system. Turk J Med Sci. 2012;42(3):471-476. doi: 10.3906/sag-1101-1469

9. Aydin C, Yildiz A, Kasap B, Yetimalar H, Kucuk I, Soylu F. Efficacy of electrosurgical bipolar vessel sealing for abdominal hysterectomy with uterine myomas more than 14 weeks in size: a randomized controlled trial. Gynecol Obstet Investig. 2012;73(4):326-329. doi: 10.1159/000336400
10. Wang K, Wu H, Li D, Liu W, Hao Q. Clinical efficacy of ligasure vessel sealing system combined with total abdominal hysterectomy in treatment of cervical carcinoma. Int J Clin Exp Med. 2017;10(3):5429-5434.

11. Landa CHB, Zaragoza JZ, Aramburu GD, Islas MLC. Uso de la pinza plasmakinetics vs material de sutura en la histerectomía total abdominal. Ginecol Obstet Mex. 2009;77(12):556-561.

12. Rossetti D, Vitale SG, Bogani G, Rapisarda AMC, Gulino FA, Frigerio L. Usefulness of vessel-sealing devices for peripartum hysterectomy: a retrospective cohort study. Updates Surg. 2015;67(3):301-304. doi: 10.1007/s13304-015-0289-0

13. Suprasongsin C, Boonyakitanon M. Comparison of Conventional Suture versus Electrosurgical Bipolar Vessel Sealing in Abdominal Hysterectomy: A randomized Control Trial. J Health Sci. 2017;21(3):415-422.

14. Dessole S, Rubattu G, Capobianco G, Caredda S, Cherchi PL. Utility of bipolar electrocautery scissors for abdominal hysterectomy. Am J Obstet Gynecol. 2000;183(2):396-399. doi: 10.1067/mob.2000.105911

15. Lauroy A, Verhaeghe C, Vidal F, Parant O, Legendre G, Guerby P. Perioperative outcomes using LigaSure compared with conventional technique in peripartum hysterectomy. Arch Gynecol Obstet. 2020;301(1):229-234. doi: 10.1007/ s00404-019-05398-0

16. Talaat A, Makboul GM. Harmonic Shears Versus Conventional Suture in Abdominal Hysterectomy. Med J Cairo Univ. 2012;80(1):527-531.

17. Hagen B, Eriksson N, Sundset M. Randomised controlled trial of LigaSure versus conventional suture ligature for abdominal hysterectomy. BJOG. 2005;112(7):968-970. doi: 10.1111/j.1471-0528.2005.00561.x

18. Bruno R, Soto-Wright V, El-Sahwi K, Dick A, Birdsall M, McLellan R. Evaluation of an advanced bipolar electrosurgical vessel sealer versus conventional ligation technique in abdominal hysterectomy. J Minim Invasive Gynecol. 2008;15(6):61S. doi: 10.1016/j.jmig.2008.09.236

19. Lakeman M, Kruitwagen RF, Vos MC, Roovers JPW. Electrosurgical bipolar vessel sealing versus conventional clamping and suturing for total abdominal hysterectomy: a randomized trial. J Minim Invasive Gynecol. 2008;15(5):547-553. doi: 10.1111/j.1471-0528.2012.03484.x

20. Maher M, Abdelaziz A. Electrosurgical Bipolar Vessel Sealing Versus Conventional Suture Technique in $\mathrm{Ab}$ dominal Hysterectomy: A Randomized Controlled Trial. 2010;36:531-537.

21. Ulubay M, Öztürk M, Fidan U, Keskin U, Firatligil FB, Kınci $\mathrm{MF}$, et al. Skin incision lengths in caesarean section. Cukurova Med J. 2016;41(1):82-86. doi: 10.17826/cutf.147190

22. Mutlu S, Benli AR. Sezeryan oncesi tahmini fetal agirlik olcumunun sezeryan insizyon uzunluguna etkisi. Ortadogu Tip Dergisi. 2017;9(3):118-122. doi: 10.21601/ortadogutipdergisi.275274

\section{Author's Contribution:}

MU conceptualized and design the study, reviewed the manuscript,

MFK wrote the manuscript,

REP collected data, made statistical analyzes, MD perfomed surgical operations, revised the manuscript. 